\author{
BO PETERSSON, ERIK TRELL, NELS-CHRISTIAN HENNINGSEN, BERTIL HOOD
}

\begin{abstract}
The causes of premature death and the associated risk factors were analysed in a cohort of 7935 middle aged men participating in a preventive population programme in Malmb. They were screened when aged 46-48 and then followed up for $3 \frac{1}{2}-8$ years. Two hundred and eighteen died, of whom $181(83 \%)$ underwent necropsy. Three major causes of death were established: cancer in $61(28 \%)$, deaths related to consumption of alcohol in $55(25 \%)$, and coronary heart disease in $50(23 \%)$.

Distinctly different patterns of risk factors were found to be associated with each of the three main causes of premature death. In death due to coronary heart disease smoking $(p=0.0062)$, serum cholesterol concentration $(p=0.00014)$, serum triglyceride concentration $(p=0.00013)$, systolic blood pressure ( $p=$ $0.000012)$, and diastolic blood pressure $(p=0.0021)$ were the strongest single determinants but diastolic blood pressure ceased to be a predictive factor in a multivariate analysis whereas all the other variables could be combined in a highly predictive logistic model. In death related to consumption of alcohol equal or even stronger associations were found for serum $\gamma$ glutamyltransferase activity $(p<0.0001)$, points scored in a questionnaire screening for alcoholism $(p<0.0001)$, and, inversely, serum cholesterol $(p=0.0046)$ and serum creatinine $(p<0.0001)$ concentrations both when applied independently and when combined in a logistic model. In death due to cancer significant associations were found for serum urate concentration $(p=0.023)$ and, inversely, serum cholesterol concentration $(p=0.056-0.031)$.

Malignant diseases and diseases related to consumption of alcohol were at least as prominent as cardiovascular disorders in causing premature death in the cohort of men studied. All three types of conditions are potentially avoidable and seem to be associated with significant and distinctive patterns of risk factors. These patterns should be used, as blood pressure and serum lipid concentrations already are, to predict the risk of premature death and indicate preventive measures.
\end{abstract}

\section{Introduction}

In recent years increasing confidence has been expressed in the view that "the second epidemiological revolution has provided the scientific weapons for the conquest of leading non-infectious diseases through preventive measures."

Knowledge of risk factors constitutes one of the most important elements in this conquest, serving as a starting point and instrument for preventive action. So far such use of risk factors has largely been confined to controlling cardiovascular disease, ${ }^{2}$

University of Lund, Malmö General Hospital, S 21401 Malmö, Sweden

BO PETERSSON, MD, associate researcher, section of preventive medicine ERIK TRELL, MD, associate professor, section of preventive medicine, departments of internal medicine and community health sciences

NELS-CHRISTIAN HENNINGSEN, MD, associate professor, department of internal medicine

BERTIL HOOD, MD, professor of internal medicine

Correspondence to: Dr E Trell. but there are other important causes of death and ill health in modern Western societies that, as evidence of analogous aetiological connections and mechanisms suggests, call for the same type of approach. The most prominent of these are disorders related to alcohol ${ }^{3}{ }^{4}$ and neoplastic diseases. ${ }^{2}{ }^{5}$

In this study we attempted to analyse the causes of premature death and the associated risk factors in a cohort of middle aged men participating in the preventive medical programme in Malmö.

\section{Subjects and methods}

SUBJECTS

The Malmö preventive programme is a long term, multiphasic programme of screening and intervention directed against the most important internal medical diseases and disabilities in industrialised Western communities-for example, coronary heart disease, hypertension, cancer, diabetes mellitus, and health problems related to smoking and alcohol consumption. ${ }^{6}$ For the present study we followed up all the men resident in Malmö and born in 1926-32; they were allotted to seven groups according to year of birth. These men were 46-48 years old at screening, which took place from 1975 to 1979 . The population comprised 10353 men, of whom $7935\left(76 \cdot 7^{\circ}{ }_{0}\right)$ participated in the screening. This study deals only with those who were screened; the others have been analysed elsewhere. ${ }^{*}$

\section{SCREENING INVESTIGATION}

The subjects were screened as previously described. ${ }^{6}$ They answered a questionnaire that included among 260 questions nine on attitude to alcohol (the Mm-MAST ${ }^{8}{ }^{9}$ ), one on abstention from alcohol, ${ }^{10}$ and several on smoking habit. ${ }^{11}$

All laboratory analyses were performed at the department of clinical chemistry, Malmö General Hospital, according to standard methods. ${ }^{6} 71213$ Serum $\gamma$ glutamyltransferase activity was analysed according to the recommendations of the Scandinavian enzyme committee ${ }^{14}$; serum concentrations of sodium, potassium, and calcium were determined by flame photometry; triglyceride, cholesterol, urate, and glucose concentrations were measured enzymatically; and creatinine concentration was determined with Jaffe's alkaline picrate method. ${ }^{12}$ An oral test of glucose tolerance was also done, ${ }^{15}$ and a relative weight index (actual/ideal weight) was calculated from the tables of Lindberg et al..$^{16}{ }^{16}$ Systolic and diastolic blood pressures at 0 and 10 minutes, standing and recumbent, were determined by standard methods. ${ }^{17}$

\section{MORTALITY}

The participants were followed up from the day after screening until the end of 1982. The longest period of follow up, for men born in 1926 and examined in 1975, was eight years, and the shortest, for men born in 1932 and examined in 1979, was three and a half years. The follow up procedure has been described previously. ${ }^{3+1-10}$ The completeness of follow up was checked up till June 1981 in a nationwide survey. By then, of the 10353 subjects originally invited to take part, $65\left(0 \cdot 6^{\circ}\right)$ could not be reliably classified as still living. Of these 65,47 had emigrated to other countries. For matching we used the Swedish 10 digit personal identification numbers.

During the period of follow up 218 men died. Of these, $181\left(83^{\prime \prime}(1)\right.$ underwent necropsy, performed in 80 cases by the department of pathology and in 101 cases by the department of forensic medicine. The three major causes of death were cancer $\left(61\left(28^{\circ} \%\right)\right.$ deaths), diseases related to alcohol $\left(55\left(25^{\circ} \circ\right)\right)$, and coronary heart disease $\left(50\left(23^{\circ}\right)\right)$. (A further 16 subjects died of other cardiovascular diseases, 32 of miscellaneous causes, and four of unknown causes.) We used a previously described definition of death due to alcohol 
related disorders. ${ }^{3}+$ This required that alcohol was indicated as the sole or major underlying cause of death and included the following subgroups: death due to an accident occurring when the subject was intoxicated with alcohol; death in an alcoholic due to an organic complication associated with alcoholism-for example cirrhosis of the liver, pancreatitis, or cardiomyopathy; suicide in an alcoholic; death due to pneumonia in an alcoholic; death due to an unknown cause in an alcoholic; death in intoxication, including sudden death in an alcoholic (subjects in this subgroup were mostly found dead and all had demonstrable concentrations of alcohol in the blood, urine, or tissues at necropsy and no evidence of other specific causes of death such as cancer, haemorrhage, or myocardial infarction); and death in states related to alcohol, such as delirium tremens.

\section{INTERVENTION}

A continuing programme of intervention operated throughout the period of follow up in outpatient clinics of the department of preventive medicine ${ }^{6}$ Intervention was indicated if at screening two consecutive readings showed any of the following: recumbent blood pressure after 10 minutes' rest $170 / 105 \mathrm{~mm} \mathrm{Hg}$ (men with blood pressure of 160-170/95-105 mm Hg were checked annually at the department of preventive medicine); serum cholesterol concentration $7.7 \mathrm{mmol} / 1$ $(298 \mathrm{mg} / 100 \mathrm{ml})$; serum triglyceride concentration $2.2 \mathrm{mmol} / 1$ $(195 \mathrm{mg} / 100 \mathrm{ml}) ; \gamma$ glutamyltransferase activity $1.4 \mu \mathrm{kat} / 1$; and blood glucose concentration at 120 minutes in an oral glucose tolerance test $7 \cdot 0 \mathrm{mmol} / 1(126 \mathrm{mg} / 100 \mathrm{ml}) .{ }^{15}$ Some other abnormal findings in the screening also indicated intervention. Some subjects were advised against smoking, ${ }^{18-20}$ and others received dietary advice to help them lose weight. ${ }^{21}$ (Details of the results of intervention in subjects with conditions related to alcohol consumption have been reported previously. ${ }^{72 *}$ )

\section{STATISTICAL METHODS}

For each subject who died two living controls were selected from the total population of participants and matched for date of screening and age (usually a difference of no more than two months). Statistical calculations were done by comparing all 218 subjects who had died and the various subgroups they constituted with the 436 matched controls and with all 7935 subjects originally screened.

Significances ( $p$ values) for single risk factors were assessed with two tailed Fisher's permutation tests. ${ }^{23}$ Comparisons of predictive value of one risk factor (main or foreground variable) when a second one (background variable) had been eliminated were done with Mantel's test. ${ }^{23}{ }^{24}$ Instead of a $\chi^{2}$ approximation, however, a more accurate method was used based on the Edgeworth expansion. ${ }^{24}$ The probabilities for death related to alcohol consumption, death due to coronary heart disease, and death due to cancer were estimated as functions of single risk factors under order restriction ${ }^{25}$ and as functions of several factors by using a logistic model. Estimation under order restriction was also applied on the probabilities obtained by logistic model (by considering the logistic model probability to be a new variable). The distributions of some of the variables were so flat that a transformation of the original scales to interval scales was necessary to achieve satisfactory approximations of the $p$ values.

\section{Results}

Table I shows the independent correlations of each of the variables screened for with total mortality and with the three main causes of death. Activity of $\gamma$ glutamyltransferase was the variable that correlated most strongly with death due to any cause, and smoking also showed a highly significant correlation. Table II shows the results of an analysis with Mantel's test of single variables when the influence of another variable was eliminated. $\gamma$ Glutamyltransferase activity and Mm-MAST score were both of independent importance in death related to alcohol consumption, but $\gamma$ glutamyltransferase activity did not show any association with death due to coronary heart disease when either systolic blood pressure or serum cholesterol concentration was taken into account. Serum concentrations of cholesterol and triglyceride were, independently of each other, significantly correlated with death due to coronary heart disease. Diastolic blood pressure, however, showed no correlation with death due to coronary heart disease when systolic blood pressure was the foreground variable.
TABLE I-Results of univariate comparison, using Fisher's permutation test, of risk factors for premature death between 218 men who had died and 436 matched controls

\begin{tabular}{|c|c|c|c|c|}
\hline \multirow[b]{2}{*}{ Variable } & \multicolumn{4}{|c|}{ Causes of death } \\
\hline & $\begin{array}{c}\text { All } \\
(\mathrm{n}=218)\end{array}$ & $\begin{array}{c}\text { Cancer } \\
(\mathrm{n}=61)\end{array}$ & $\begin{array}{c}\text { Coronary } \\
\text { heart } \\
\text { disease } \\
(n=50)\end{array}$ & $\begin{array}{l}\text { Deaths } \\
\text { related to } \\
\text { alcohol } \\
(\mathrm{n}=55)\end{array}$ \\
\hline $\begin{array}{l}\text { Y Glutamyltransferase } \\
\text { Alcohol abstention } \\
\text { Mm-MAST score } \\
\text { Smoking category } \\
\text { Serum cholesterol } \\
\text { Serum triglyceride } \\
\text { Systolic blood pressure } \\
\text { Diastolic blood pressure } \\
\text { Relative weight } \\
\text { Serum urate } \\
\text { Serum creatinine }\end{array}$ & $\begin{array}{l}0.0001 \\
\text { NS } \\
0.016 \\
0.0002 \\
\text { NS } \\
0.022 \\
0.0013 \\
\text { NS } \\
\text { NS } \\
\text { NS } \\
0.029+\end{array}$ & $\begin{array}{c}\text { NS } \\
\text { NS } \\
\text { NS } \\
\text { NS } \\
0.056^{*+} \\
\text { NS } \\
\text { NS } \\
\text { NS } \\
\text { NS } \\
0.023 \\
\text { NS }\end{array}$ & $\begin{array}{l}0.034 \\
\text { NS } \\
\text { NS } \\
0.0062 \\
0.00014 \\
0.00013 \\
0.000012 \\
0.0021 \\
\text { NS } \\
\text { NS } \\
\text { NS }\end{array}$ & $\begin{array}{l}<\theta .0001 \\
\text { NS } \\
<0.0001 \\
\text { NS } \\
0.0046+ \\
\text { NS } \\
\text { NS } \\
\text { NS } \\
\text { NS } \\
\text { NS } \\
0.0001+\end{array}$ \\
\hline
\end{tabular}

${ }^{*} p=0.031$ when men who died were compared with all subjects screened.

p Inverse correlation.

TABLE II-Results of analysis with Mantel's test for single variables when the influence of another variable was eliminated

\begin{tabular}{|c|c|c|c|}
\hline Cause of death & Main variable & Background variable & $\begin{array}{l}\text { Two sided } \\
\text { p value }\end{array}$ \\
\hline $\begin{array}{l}\text { Conditions related } \\
\text { to alcohol }\end{array}$ & $\left\{\begin{array}{l}\gamma \text { Glutamyltransferase } \\
\gamma \text { Glutamyltransferase } \\
\gamma \text { Glutamyltransferase } \\
\text { Mm-MAST score }\end{array}\right.$ & $\begin{array}{l}\text { Mm-MAST score } \\
\text { Cholesterol } \\
\text { Creatinine } \\
\gamma \text { Glutamyltransferase }\end{array}$ & $\begin{array}{l}0.00047 \\
\leq 0.0001 \\
0.0001 \\
<0.0001\end{array}$ \\
\hline $\begin{array}{l}\text { Coronary heart } \\
\text { disease }\end{array}$ & $\left\{\begin{array}{l}\gamma \text { Glutamyltransferase } \\
\gamma \text { Glutamyltransferase } \\
\text { Cholesterol } \\
\text { Triglyceride } \\
\text { Systolic blood pressure } \\
\text { Diastolic blood pressure }\end{array}\right.$ & $\begin{array}{l}\text { Cholesterol } \\
\text { Systolic blood pressure } \\
\text { Triglyceride } \\
\text { Cholesterol } \\
\text { Diastolic blood pressure } \\
\text { Systolic blood pressure }\end{array}$ & $\begin{array}{l}\text { NS } \\
\text { NS } \\
0 \cdot 0056 \\
0 \cdot 0024 \\
0 \cdot 0013 \\
\text { NS }\end{array}$ \\
\hline
\end{tabular}

Figure 1 shows probability of death related to alcohol consumption as a function of the three variables $\gamma$ glutamyltransferase activity, Mm-MAST score, and serum creatinine concentration. Figure 2 shows the probability of death due to coronary heart disease as a function of the variables serum cholesterol concentration, triglyceride concentration, and systolic blood pressure (left) and of smoking (centre). The figures also show the probabilities of death due to cardiac heart disease and to alcohol consumption as calculated by logistic models combining the individual variables. The combination of $\gamma$ glutamyltransferase activity, Mm-MAST score, and creatinine concentration gave a moderately improved prediction of death from disorders related to alcohol consumption in comparison with that
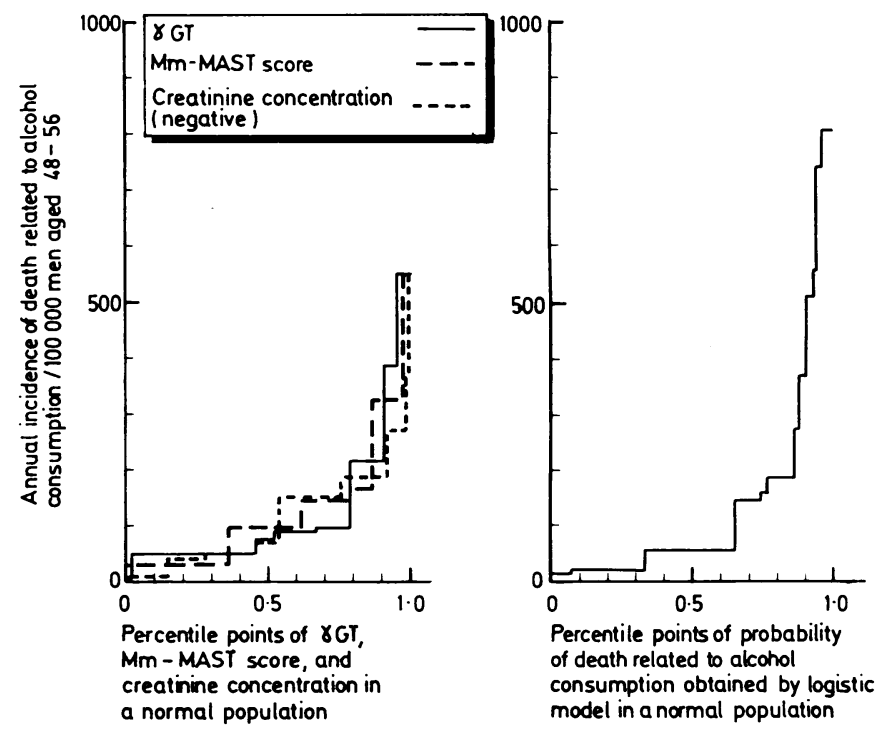

FIG 1-Probability of death related to alcohol consumption as a function of $\gamma$ glutamyltransferase activity ( $\gamma$ GT), Mm-MAST score, and serum creatinine concentration (left) and as a function of these variables combined in a logistic model (right). 
given by each of the single variables; and the combination of cholesterol concentration, triglyceride concentration, systolic blood pressure, and smoking habit gave an equally improved prediction of death due to coronary heart disease, but its predictive power and discrimination in terms of absolute numbers of deaths in the same population were lower than given by the logistic function for death related to alcohol consumption. Table III summarises this and compares the predictive power of multiple logistic functions for death due to coronary heart disease and to disorders related to alcohol with each other and with a similar function including the variables with the non-participants. ${ }^{3}{ }^{4}$ This makes it particularly remarkable that deaths related to alcohol consumption occurred so often and that $\gamma$ glutamyltransferase activity was the single variable that correlated most strongly not only with this cause but with all the causes of death (table I).

When we analysed the major causes of death (cancer, coronary heart disease, disorders related to alcohol) separately, however, we found that $\gamma$ glutamyltransferase activity was associated only with deaths related to alcohol consumption (table I) and
FIG 2-Probability of death due to coronary heart disease as a function of serum cholesterol concentration, triglyceride concentration, and systolic blood pressure (left), of smoking habit (centre), and of these variables combined in a logistic model (right).
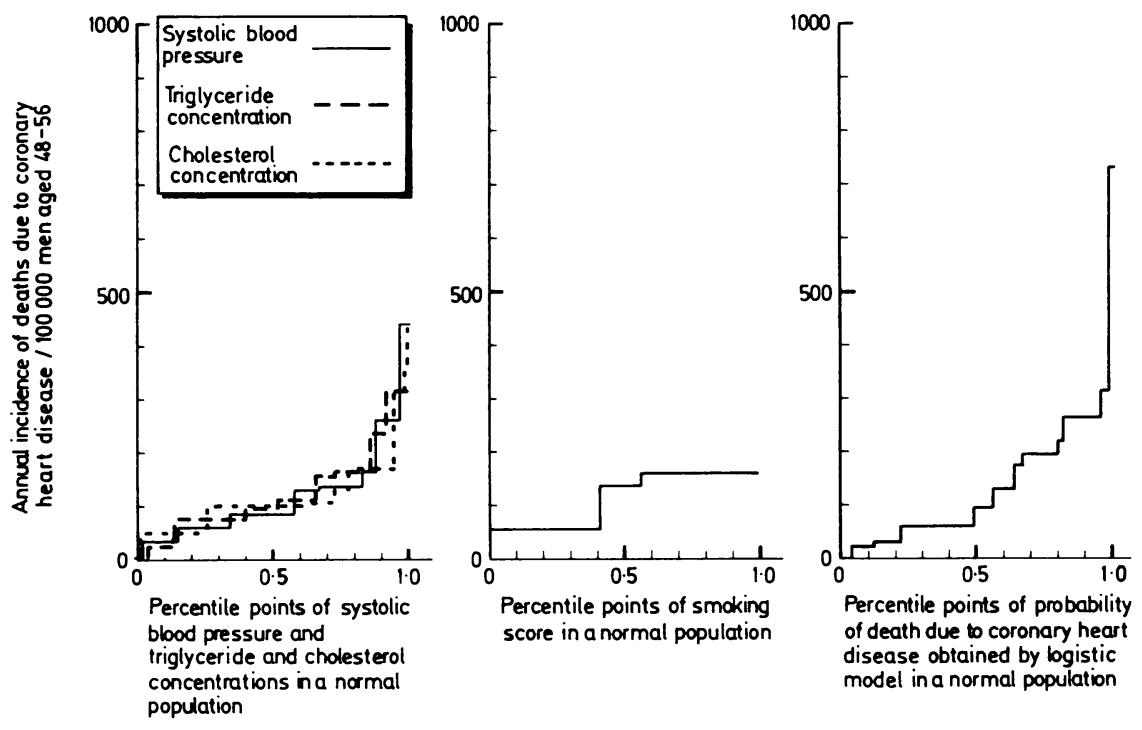

TABLE III-Annual incidence of death due to cardiac heart disease, conditions related to alcohol intake, and cancer/100 000 men aged 48-56 in consecutive percentiles of the respective determinant functions as calculated by logistic models combining risk factors

\begin{tabular}{|c|c|c|c|c|}
\hline \multirow[b]{2}{*}{ Percentile } & \multicolumn{4}{|c|}{ Causes of death } \\
\hline & $\begin{array}{l}\text { Coronary } \\
\text { heart } \\
\text { disease } \\
\text { (excluding } \\
\text { smoking } \\
\text { habit) }\end{array}$ & $\begin{array}{l}\text { Coronary } \\
\text { heart } \\
\text { disease } \\
\text { (including } \\
\text { smoking } \\
\text { habit) }\end{array}$ & $\begin{array}{l}\text { Conditions } \\
\text { related to } \\
\text { alcohol } \\
\text { consumption }\end{array}$ & Cancer \\
\hline 0.05 & & 24 & 8 & 53 \\
\hline $0 \cdot 10$ & 39 & 30 & 14 & 65 \\
\hline 0.20 & 50 & 33 & 21 & 79 \\
\hline 0.30 & 60 & 55 & 30 & 91 \\
\hline 0.40 & 72 & 67 & 43 & 105 \\
\hline 0.50 & 86 & 78 & 60 & 119 \\
\hline 0.60 & 103 & 93 & 77 & 136 \\
\hline 0.70 & 120 & 118 & 116 & 160 \\
\hline 0.80 & 145 & 155 & 173 & 178 \\
\hline 0.90 & 204 & 252 & 369 & 232 \\
\hline 0.95 & & 340 & 531 & 264 \\
\hline 0.97 & & 406 & 646 & $\begin{array}{l}305 \\
384\end{array}$ \\
\hline$(1 \cdot 00)$ & & 637 & 1051 & 384 \\
\hline
\end{tabular}

cholesterol concentration (inversely), urate concentration, and smoking habit for deaths due to cancer. The logistic model for deaths due to disorders related to alcohol consumption showed a better discrimination at both ends of its distribution than that for deaths due to coronary heart disease, in which all established risk factors for coronary heart disease in middle aged men were used. The predictive power of the logistic model for risk of death due to cancer was appreciably inferior, particularly in its ability to indicate low risk of death in malignant disease.

\section{Discussion}

Our study population comprised all those middle aged men who participated in the original screening investigation - that is, about three quarters of all the men of the same age resident in Malmö. Importantly, advanced disease related to alcohol consumption was underrepresented in the participants compared not with deaths due to cancer, which is interesting because $\gamma$ glutamyltransferase activity was introduced early as a test for malignancy of the liver. ${ }^{26}$ Results from Mm-MAST, the short questionnaire to assess attitudes to alcohol that reflects habits of consumption rather than degree of individual biological complication, ${ }^{912}$ were interestingly enough also independently and almost as strongly correlated with death related to alcohol as was $\gamma$ glutamyltransferase activity. The problem with Mm-MAST, however, is the high proportion of false positive results it gives in testing for disorders due to alcohol consumption. About a third of the subjects we screened answered in the affirmative to two or more of the Mm-MAST questions, which we had taken as the screening cut off point of the test. ${ }^{8-10}$ The test thus gives a high yield of patients who have to be subjected to further interrogation and investigation if it is used alone; moreover, it is hard to use a questionnaire as a therapeutic instrument in the ensuing prevention of disorders related to alcohol. ${ }^{9}$ In conjunction with a programme of internal medical screening and intervention Mm-MAST score is therefore most usefully applied in combination with $\gamma$ glutamyltransferase activity and other variables.

The strong inverse relation between serum creatinine concentration and death related to alcohol consumption is of particular interest for several reasons. Firstly, our finding confirms similar observations in two previous studies ${ }^{27} 28$; secondly, this inverse relation may be used with other indicators such as $\gamma$ glutamyltransferase activity and Mm-MAST score in multivariate and multiple logistic risk factor functions (fig 1); and, finally, serum creatinine concentration tends to decrease throughout the various stages of diseases related to alcohol ${ }^{12}$ whereas many classical markers of alcohol disorders, such as blood pressure, ${ }^{17}{ }^{29-33}$ serum urate concentration, ${ }^{34}{ }^{35}$ and triglyceride concentration $^{36}$ seem to indicate only the initial disturbances in health ${ }^{12}$ and not the risk of death (table I). The explanation for the statistically confirmed absence of an association between markers and the later stages of diseases caused by alcohol consumption (which did occur, however, in previous health 
screening studies of the same population ${ }^{12}$ ) relative to the present end point is probably that early and advanced stages of disorders related to alcohol consumption are associated with different metabolic and nutritional states. ${ }^{37-40}$

Tests that are disease specific are rare, and $\gamma$ glutamyltransferase activity is no exception to this rule. The mechanism for the increase of $\gamma$ glutamyltransferase activity with alcohol consumption is probably enzyme induction, which may be caused by other agents as well, such as drugs. ${ }^{412}$ Scepticism has also been expressed about the use of $y$ glutamyltransferase activity to determine whether subjects have a high alcohol consumption. ${ }^{43} \quad \gamma$ Glutamyltransferase activity relates predominantly, however, to disorders caused by alcohol consumption, in connection with which it has so far seemed to be superior to any other proposed single measurement-for example, other liver enzyme activities, ${ }^{44}$ serum urate concentration, serum ferritin concentration, ${ }^{45}$ mean corpuscular volume $^{46}{ }^{47}$ serum glutamate dehydrogenase activity, ${ }^{48}$ and the ratio between $\alpha$ amino- $\mathrm{N}$-butyric acid and leucine. ${ }^{49}$ Thus its judicious use in well controlled investigations of somatic health should be encouraged but its properties further studied. In developed ${ }^{50}$ and developing ${ }^{51}$ countries health problems caused by alcohol consumption constitute one of the leading non-infectious epidemics. In these disorders, as in cardiovascular diseases, "the opportunities for improving health by the prevention of disease are at least as great and possibly greater". than those afforded by curative treatment in hospital.

Although several studies have focused on risk factors for coronary heart disease, especially in middle aged men, ${ }^{52.54}$ the role of lipids in coronary heart disease is still controversial as far as the independent role of triglyceride concentration is concerned. ${ }^{545}$ In the present investigation both serum cholesterol and triglyceride concentrations were strongly significant risk factors ${ }^{56}$ and contributed independently to the risk of death (table II, fig 2). Furthermore, systolic as well as diastolic blood pressures were significantly associated with death due to coronary heart disease (table I), but in the multivariate analysis the independent role of diastolic blood pressure disappeared (table II). This accords with the findings in the Framingham study. ${ }^{5}$ In general, all our results regarding those who died due to coronary heart disease corresponded well with the results of earlier studies.

One of the most important aspects of risk factors in the control of diseases is discriminating in the lower end of the distribution-that is, the ability not only to identify an appreciable proportion of the subjects actually at risk but to clear as many as possible of the rest of the population from the risk of the end point in question. This was first achieved in the cardiovascular diseases. ${ }^{58}$ In comparison, our logistic model for cancer was of inferior strength in its lower range (table III). In the men, however, the multiple logistic function of risk factors for death related to alcohol consumption was more powerful in both ends of its distribution than the corresponding logistic function of established risk factors for death due to coronary heart disease. We believe that these results support recent suggestions that these are potentially avoidable, major non-infectious diseases in Western societies that "are capable of being prevented by means that have not yet been fully implemented.".

This study was supported by the Swedish Council for Planning and Coordination of Research and Arbetsmarknadens Försäkringsaktiebolag.

\section{References}

1 Jonas S, Arnold CB. The place of prevention in medical education: past, present, and future Introduction. Prev Med 1981;10:661-2.

2 Doll R. Prospects for prevention. Br Med f 1983;286 :445-53.

${ }^{3}$ Petersson B, Kristenson H, Sternby NH, Trell E, Fex G, Hood B. Alcohol consumption and premature death in middle aged men Br Med f 1980;280:1403-6.

4 Petersson B, Krantz P, Kristenson H, Trell E, Sternby NH. Alcohol- related death: a major contributor to mortality in urban middle-aged men. Lancet 1982 ;ii:1088-90.

Fox P.J, Ebeling K, Eklurd G, et al. The role of epidemiology in cancer control. Report on a meeting of the World Health Organisation, Lyons, 2-4 November 1982. Copenhagen: WHO, 1983. (ICP/CAN 015.)

6 Trell E. Community-based preventive medical department for individual risk factor assessment and intervention in an urban population. Prev Med 1983;12:397-402.

${ }^{7}$ Kristenson H, Trell E, Hood B. Serum gamma-glutamyl transferase in screening and continuous control of heavy drinking in middle-aged men. Am 7 Epidemiol 1981;114:862-72.

* Kristenson H, Trell E. Indicators of alcohol consumption. Comparisons between a questionnaire (Mm-MAST), interviews and serum-gammaglutamyltransferase (GGT) in a health survey of middle-aged males. Br F Addict 1982;77:297-305.

${ }^{9}$ Petersson B, Trel! E, Kristenson $\mathrm{H}$. Comparison of $\gamma$-glutamyltransferase and questionnaire test as alcohol indicators in different risk groups. Drug Alcohol Depend 1983;11:279-86.

11) Petersson B, Trell E, Kristenson H. Alcohol abstention and premature mortality in middle-aged men. $\mathrm{Br}$ Med $\mathcal{F} 1982 ; 285: 1457-9$.

11 Janzon L, Lindell SE, Trell E. Smoking and disease. Attitudes and knowledge in middle-aged men. Scand 7 Soc Med 1981;9:127-33.

12 Petersson B, Trell E, K.ristensson H, Fex G, Yettra M, Hood B. Comparison of gamma-glutamyltransferase and other health screening tests in average middle-aged males, heavy drinkers and alcohol non-users. Scand f Clin Lab Invest $1983 ; 43: 141-9$.

13 Petersson B, Trell E. Raised serum urate concentration as risk factor for premature mortality in middle-aged men: relation to death from cancer. Br Med F 1983;287:7-9.

It Scandinavian Enzyme Committee. Recommended methods for the determination of gamma-glutamyltransferase in blood. Scand $\mathcal{F}$ Clin Lab Invest $1976 ; 36: 119-25$.

15 Janzon L, Berntorp K, Hanson M, Lindell SE, Trell E. Glucose tolerance and smoking: a population study of oral and intravenous glucose tolerance tests in middle-aged men. Diabetologia 1983;25:86-8.

${ }^{16}$ Lindberg W, Natvig H, Rygh A, Svendsen K. Höyde og vektsundersökelser hos voksne menn og kvinner. Tidsskr Nor Laegeforen 1956;76:231-71.

17 Henningsen NC, Janzon L, Trell E. Influence of carboxyhemoglobin, gamma-glutamyl-transferase, body weight, and heart rate on blood pressure in middle-aged men. Hypertension 1983;5:560-3.

18 Janzon L, Lindell SE, Trell E, Larme P. Smoking habits and carboxyhemoglobin. 7 Epidemiol Community Health $1981 ; 35: 271-3$.

19 Trell E, Janson L, Lindell SE, et al. Rauchgewohnheiten, Kohlenmonoxydhämoglobin und Lungenkrankheiten. Prax Klin Pneumol 1983;37:673-5.

20 Trell E, Trell L, Janzon L, Laurell P, Korsgaard R. Verbesserung der Motivation zur Rauchentwöhnung bei Individuen mit genetischen Risikofaktoren für Lungenkrebsentwicklung. Prax Klin Pneumol $1983 ; \mathbf{3 7}: 687-90$

${ }^{21}$ Larsson L, Trell E. Nutritionist in preventive medicine. Some experiences from the department of preventive medicine in Malmö. Socialmedicinsk Tidsskrift 1983;60:325-6.

${ }^{22}$ Kristenson $\mathrm{H}$, Öhlin $\mathrm{H}$, Hulthén-Nosslin MB, Trell E, Hood B. Identification and intervention of heavy drinking in middle-aged men: results and follow-up of 24-60 months of long-term study with randomized controls. Alcoholism: Clinical and Experimental Research $1983 ; 7: 203-9$.

${ }^{23}$ Mantel N. Chi-square tests with one degree of freedom: extensions of the Mantel-Haenszel procedure. Fournal of the American Statistical Association 1963;58:690-700.

${ }^{24}$ Cramér H. Mathematical methods of statistics. Princeton: Princeton University Press, 1946.

25 Barlow RE, Bartholomew DJ, Bremner JM, Brunk HD. Statistical inference under order restrictions. New York: Wiley, 1972.

${ }^{26}$ Aronsen KF, Nosslin B, Pihl B. The value of gamma-glutamyl transpeptidase as a screen test for liver tumor. Acta Chir Scand 1970;136: $17-22$.

${ }^{27}$ Chan-Yeung M, Ferreira P, Frolich J, Schulzer M, Tan F. The effects of age, smoking, and alcohol on routine laboratory tests. Am $\mathcal{f}$ Clin Pathol $1981 ; 75: 320-6$.

28 Gill GV, Baylis PH, Flear CTG, Skillen AW, Diggle PH. Acute biochemical responses to moderate beer drinking. $B r$ Med 7 1982;285:1770-3.

29 Wälimäki M, Ylikahri R. Alcohol and sex hormones. Scand $\mathcal{f}$ Clin Lab Invest $1981 ; 49: 99-105$.

${ }^{30}$ Klatsky AR, Friedman GD, Siegelaub AB, Gérard MJ. Alcohol consumption and blood pressure. Kaiser-Permanente multiphasic health examination data. $N$ Engl f Med 1977;276:1194-1200.

${ }^{31}$ Larbi EB, Cooper RS, Stamler J. Alcohol and hypertension. Arch Intern Med 1983;143:28-9.

32 Henningsen NC, Ohlsson O, Mattiasson I, Trell E, Kristensson H, Hood B. Hypertension, levels of serum gamma glutamyltranspeptidase and degree of blood pressure control in middle-aged males. Acta Med Scand $1980 ; 207: 245-51$.

${ }^{33}$ Mathews JD. Alcohol use, hypertension and coronary heart disease. Clinical Science and Molecular Medicine 1976;51:661-3.

${ }^{34}$ Lieber CS, Jones DP, Losowsky MS, Davidson CS. Interrelation of uric acid and ethanol metabolism in man. $\mathcal{F}$ Clin Invest 1962;41:1863-70.

35 Faller J, Fox IH. Ethanol-induced hyperuricemia. Evidence for increased urate production by activation of adenine nucleotide turnover. $N$ Engl f Med $1982 ; 307: 1598-602$. 
36 Chait A, February AW, Mancini M, Lewis B. Clinical and metabolic study of alcoholic hyperlipidaemia. Lancet 1972 ;ii:62-4.

${ }^{37}$ Higuchi T, Nakamura T, Uchino H. Enhanced renal clearance of uric acid in hepatic cirrhosis. Isr F Med Sci 1981;17:1015-8.

${ }^{38}$ Grande F, Amatuzio DS. The influence of ethanol on serum cholesterol concentration. Minn Med 1960;43:731-5.

${ }^{39}$ Belfrage P, Berg B, Hägerstrand I, et al. Alterations of lipid metabolism in healthy volunteers during long-term ethanol intake. Eur $\mathcal{f}$ Clin Invest $1977 ; 7: 127-31$.

40 Castelli WP, Gordon T, Hjortland MC, et al. Alcohol and blood lipids. The cooperative lipoprotein phenotyping study. Lancet 1977;ii:153-5.

41 Rosalki SB, Tarlow D, Rau D. Plasma gamma glutamyltranspeptidase elevation in patients receiving enzyme-inducing drugs. Lancet 1971;ii: 376-7.

42 Teschke R, Neuefeind M, Nishimura N, Strohmeyer G. Hepatic gammaglutamyltransferase activity in alcoholic fatty liver: comparison with other liver enzymes in man and rats. Gut 1983;24:625-30.

43 Penn R, Worthington DJ. Is serum gamma-glutamyltransferase a misleading test? Br Med $\mathcal{F} 1983 ; 286: 531-5$.

${ }^{44}$ Horner F, Kellen JA, Kingstone E, Maharaj N, Malkin A. Dynamic changes of serum gamma-glutamyl transferase in chronic alcoholism. Enzyme 1979;24:217-23.

${ }^{45}$ Kristenson H, Fex G, Trell E. Serum ferritin, gammaglutamyl-transferase and alcohol consumption in healthy middle-aged men. Drug Alcohol Depend $1981 ; 8: 43-50$.

46 Wu A, Chanarin I, Leevy AJ. Macrocytosis of chronic alcoholism. Lancet $1974 ; \mathrm{i}: 829-31$.

47 Bagrel A, d'Houtaud A, Gueguen R, Siest G. Relation between reported alcohol consumption and certain variables in an unselected population. Clin Chem 1979;25:1242-6.
48 Van Waes L, Lieber CS. Glutamate dehydrogenase: a reliable marker of liver cell necrosis in the alcoholic. $\mathrm{Br} \mathrm{Med} \mathcal{F} 1977$;ii:1508-10.

19 Shaw S, Stimmel B, Lieber CS. Plasma alfa-amino-n-butyric acid/leucine ratio: an empirical biochemical marker of alcoholism. Science $1976 ; \mathbf{1 9 4}$. 1057-8.

${ }^{50}$ Lieber CS. A public health approach for the control of the disease of alcoholism. Alcoholism 1982;6:171-7.

${ }^{51}$ Edwards G. Drinking problems: putting the third world on the map. Lancet 1979 ;ii:402-6.

52 Dawber TR. The Framingham study. The epidemiology of atherosclerotic disease. Cambridge: Harvard University Press, 1980.

${ }^{53}$ Keys A. Seven countries. A multivariate analysis of death and coronary heart disease. Cambridge: Harvard University Press, 1980.

${ }^{54}$ Böttiger LE, Carlson LA. Risk factors for death for males and females. A study of the death pattern in the Stockholm Prospective Study. Acta Med Scand 1982;211:437-42.

55 Hulley SB, Rosenman RH, Bawol RD, Brand RJ. Epidemiology as a guide to clinical decisions: the association between triglyceride and coronary heart disease. $N$ Engl f Med 1980;302:1383-9.

56 Petersson B, Trell E. Premature mortality in middle-aged men: serum cholesterol as risk factor. Klin Wochenschr 1983;63:795-801.

57 Kannel W, Gordon T, Schwartz MJ. Systolic versus diastolic blood pressure and risk of coronary heart disease: the Framingham study. Am F Cardiol 1971 ;27:335-46.

${ }^{58}$ Wilhelmsen L, Wedel H, Tibblin G. Multivariate analysis of risk factors for coronary heart disease. Circulation 1973;48:950-8.

(Accepted 3 February 1984)

\title{
Flexible induction dose regimen for warfarin and prediction of maintenance dose
}

\author{
A FENNERTY, J DOLBEN, P THOMAS, G BACKHOUSE, D P BENTLEY, I A CAMPBELL, \\ P A ROUTLEDGE
}

\begin{abstract}
Fifty patients with venous thromboembolic disease being treated by heparin infusion received a three day warfarin induction regimen tailored according to the prothrombin time (British comparative ratio) measured on days 2 and 3 . A prediction of the final maintenance dose of warfarin was made on the basis of a prothrombin time measured on day 4. All patients were safely anticoagulated by day 6 , and the prediction was accurate to within $1 \mathrm{mg}$ in 46 patients. Predicted and actual maintenance doses were closely related $(r=0.867 ; n=50$; p $<0.001$ ).

This scheme should prove helpful in the control of anticoagulation, particularly in patients likely to be sensitive to warfarin, and should shorten hospital stay.
\end{abstract}

Departments of Medicine, Haematology, and Thoracic Medicine, Llandough Hospital, Penarth, S Glamorgan

A FENNERTY, MB, MRCP, registrar

$\mathrm{J}$ DOLBEN, $\mathrm{MB}, \mathrm{BS}$, senior house officer

P THOMAS, MB, BS, senior house officer

G BACKHOUSE, FIMLS, technician

D P BENTLEY, MRCP, MRCPATH, consultant haematologist

I A CAMPBELL, MD, FRCPED, consultant thoracic physician

Department of Pharmacology and Therapeutics, Welsh National School of Medicine, Heath Park, Cardiff CF4 4XN

P A ROUTLEDGE, MD, MRCP, consultant physician and senior lecturer

Correspondence to: Dr P A Routledge.

\section{Introduction}

A relation between the prothrombin time after a loading dose of warfarin and the eventual maintenance dose of warfarin has been well described, ${ }^{1-5}$ and from the derived regression equations a prediction can be made of the maintenance warfarin dose. Until recently the British National Formulary suggested a warfarin loading regimen of $10 \mathrm{mg}$ on each of three consecutive days, but this may cause up to $35 \%$ of patients to be over anticoagulated by the fourth day. ${ }^{6}{ }^{7}$ Patients' stay in hospital may be unnecessarily prolonged while their prothrombin time falls to within the therapeutic range and while a tentative maintenance warfarin dose is established.

The current edition of the British National Formulary now recommends an induction dose of $10 \mathrm{mg}$ warfarin daily for three days with British comparative ratios measured before the first dose and on the second and third days, so that the subsequent warfarin dose may be modified if required. ${ }^{8}$ No guidelines on dose adjustment are given.

We have attempted to design a flexible three day loading dose regimen, aimed at bringing the British comparative ratio smoothly into the therapeutic range, and to predict the maintenance dose of warfarin on the basis of a British comparative ratio measured on day 4 .

\section{Method}

Patients with venous thromboembolic disease presenting to physicians, surgeons, and gynaecologists at Llandough Hospital were heparinised using a continuous intravenous infusion maintaining the kaolin-cephalin clotting time (Bell and Alton platelet substitute; 